\title{
Nanocellulose in Food Science and Technology - Potential, Advantages and Gaps of Research
}

\author{
Talita Szlapak Franco* and Graciela Inez Bolson de Muniz \\ Department of Forest Engineering, Federal University of Parana, Brazil
}

*Corresponding author: Talita Szlapak Franco, Federal University of Parana, Av Prefeito Lothário Meissner, 632, Curitiba, Parana, Brazil, 80410-170

Submission: August 18, 2017; Published: April 03, 2018

\begin{abstract}
Abbreviations: CNF: Cellulose Nano Fibers; CNC: Cellulose Nano Crystals; BNC: Bacterial Nano Cellulose; GRAS: Generally Recognized As being Safe; FDA: Food and Drug Administration; EU: Europe Union.
\end{abstract}

\section{Introduction}

Since the first description of cellulose molecule in 1838 by the French chemist Anselme Payen, passing through the obtention of nanocellulose in 1977 [1], until the published researches up to 2017, too many advances and different approaches were given to this multifunctional polysaccharide from pulp and paper industry to medical applications. Although the first US Patent submitted by Turbak and co-workers considered nanocellulose a food additive, this product was not commercially exploited because of the high production costs, however, now this panorama is changing with industries focusing their plants in the production of the nanopolymer [2].

The fundamental characteristics which turn nanocellulose so unique and functional are: its huge surface area and aspect ratio (at least ten times larger than that of cellulose fibers), extensive hydrogen bonding ability; and the fact that it can be isolated from totally renewable sources [3]. Cellulose Nano Fibers (CNF), Cellulose Nano Crystals (CNC) and Bacterial Nanocellulose (BNC) are being investigated for its food application, as fat replacer [4,5] stabilizer [6], thickening, gelling and water binding properties [7,8] cry protective medium for probiotics [9] and widely as reinforcement phase in nano composites for a variety of applications, including food packaging [10]. Beyond the properties that made nanocellulose an excellent food additive, some lines of studies considered potential functional properties, where it can improve the health of consumers, acting like a dietary fiber [11].

As discussed, nanocellulose is an abundant and sustainable material, with potential applications in the food industry. However, only bacterial and powdered cellulose have their application regulated and is Generally Recognized As being Safe (GRAS) by Food and Drug Administration (FDA) and as food additive by Europe Union (EU). The nano scale derivatives still exhibit indefinite properties and thus, may expose humans and environment to unknown risks. Some studies already pointed to the safety of nanocellulose in tests in vivo and in vitro, but when we talk about food, we comprise a complex matrix, without total knowledge of the interaction of the nanocellulose with other ingredients and the physical or chemical changes that its molecule could suffer during the food production or digestion [12-14]. With a great number of researches that prove nanocellulose high functionalities in lower doses; its chemical and physical stabilities and even its secure application, a demand in the food industry is emerging for "tailored nanocellulose for food application". This fact, guide prospective researches targeted in fabrication of nanocellulose for these needs, as well as: new sources of nanocellulose extraction; technological and nutritional properties evaluation; new products; safety tests and most importantly, the question about the regulation for food application. An integration of governments, universities, industries and research centers could improve the solution of the issues that delay the consumers to take advantage of the benefits of nanotechnology in their lives, in such a simple way as food is.

\section{References}

1. Turbak AF, Snyder FW, Sandberg KR (1983) Micro fibrillated cellulose, a new cellulose product: properties uses and commercial potential. J Appl Polym Sci Appl Polym Symp 37: 815-827.

2. Gomez CH, Serpa A, Velazquez-Cock J, Gañan P, Castro C, et al. (2016) Vegetable nanocellulose in food science: A review. Food Hydrocolloids 57: 178-186.

3. Klemm D, Kramer F, Moritz S, Lindstrm MA, Gray D, et al. (2011) Nanocelluloses: A new family of nature based materials. Angew Chem Int Ed Engl 50(24): 5438-5466.

4. Golchoobi L, Alimi M, Shokoohi S, Yousefi H (2016) Interaction between nano fibrillated cellulose with guar gum and carboxy methyl cellulose in low-fat mayonnaise. J Text Stud 47: 403-412. 
5. Marchetti L, Muzzio B, Cerrutti P, Andréas S, Califano AN (2017) Bacterial nanocellulose as novel additive in low-lipid low-sodium meat sausages. Effect on quality and stability. Food Structure 14: 52-59.

6. Capron I, Rojas OJ, Bordes R (2017) Behavior of nanocelluloses at interfaces. Current Opinion in Colloid \& Interface Science 29: 83-95.

7. Shi Z, Zhang Y, Phillips GO, Yang G (2014) Utilization of bacterial cellulose in food. Food Hydrocolloids 35: 539-545.

8. Corral ML,Cerrutti P,Vazquez A, Califano A (2017) Bacterial nanocellulose as a potential additive for wheat bread. Food Hydrocolloids 67: 189-196.

9. Nahr FK, Mokarram RR, Hejazi MA, Ghanbarzadeh B, Khiyabani MS, et al. (2015) Optimization of the nanocellulose based cryoprotective medium to enhance the viability of freeze dried Lactobacillus plantarum using response surface methodology. LWT-Food Science and Technology 64(1): 326-332.
10. Azeredo HMC, Rosa MF, Mattoso LH (2017) Nanocellulose in bio-based food packaging applications. Industrial Crops and Products 97: 664-671.

11. Andrade DR, Mendonça MH, Helm CV, Magalhães WL, de Muniz GI, et al. (2015) Assessment of nano cellulose from peach palm residue as potential food additive: part II: preliminary studies. J Food Sci Technol 52(9): 5641-5650.

12. Szakal C, Roberts SM, Westerhoff P, Bartholomaeus A, Buck N, et al. (2014) Measurement of nanomaterials in foods: integrative consideration of challenges and future prospects. ACS Nano 8(4): 3128-3135.

13. Picó Y (2016) Challenges in the determination of engineered nanomaterials in foods. Trends in Analytical Chemistry 84: 149-159.

14. Payen A, Hebd C, Seances R (1838) Academy of Science 7: 1052-1125.
Creative Commons Attribution 4.0 International License

For possible submissions Click Here
Submit Article

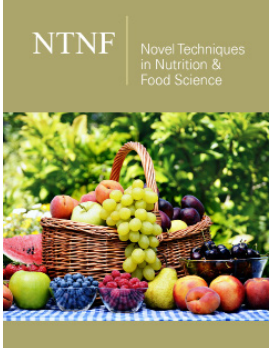

Novel Techniques in Nutrition and Food Science

\section{Benefits of Publishing with us}

- High-level peer review and editorial services

- Freely accessible online immediately upon publication

- Authors retain the copyright to their work

- Licensing it under a Creative Commons license

- Visibility through different online platforms 